\title{
IMPLEMENTASI STRATEGI PEMBELAJARAN AKTIF TIPE INSTANT ASSESSMENT UNTUK MENINGKATKAN PRESTASI BELAJAR KOMPETENSI DASAR MENGELOLA KARTU UTANG SISWA KELAS XI AKUNTANSI 2 SMK YAPEMDA 1 SLEMAN TAHUN AJARAN 2017/2018
}

\author{
THE IMPLEMENTATION OF ACTIVE LEARNING STRATEGY TYPE INSTANT \\ ASSESSMENT TO IMPROVE LEARNING ACHIEVEMENT OF MANAGING \\ PAYABLE CARD ON STUDENT OF CLASS XI ACCOUNTING 2 SMK YAPEMDA 1 \\ SLEMAN IN THE ACADEMIC YEAR OF 2017/2018
}

\author{
Oleh: \\ Nia Puspita Dewi \\ Pendidikan Akuntansi Universitas Negeri Yogyakarta \\ dniapuspita@yahoo.co.id
}

Siswanto

Staf Pengajar Jurusan Pendidikan Akuntansi Universitas Negeri Yogyakarta Siswanto@uny.ac.id

\begin{abstract}
Abstrak
Penelitian ini bertujuan untuk meningkatkan Prestasi Belajar Kompetensi Dasar Mengelola Kartu Utang melalui Implementasi Strategi Pembelajaran Aktif Tipe Instant Assessment pada siswa kelas XI Akuntansi 2 SMK YAPEMDA 1 Sleman Tahun Ajaran $2017 / 2018$.

Jenis penelitian ini yaitu penelitian tindakan kelas yang dilaksanakan dalam dua siklus. Masing-masing siklus terdiri dari satu kali pertemuan. Setiap siklus terdiri dari empat tahap yaitu perencanaan tindakan, pelaksanaan tindakan, pengamatan tindakan dan refleksi tindakan. Subjek dalam penelitian ini adalah siswa kelas XI Akuntansi 2 SMK YAPEMDA 1 Sleman Tahun Ajaran 2017/2018 yang berjumlah 20 siswa. Indikator keberhasilan pada penelitian ini adalah apabila terjadi peningkatan nilai rata-rata siswa setelah tindakan (post test) siklus I ke nilai rata-rata siswa setelah tindakan (post test) siklus II dan apabila $75 \%$ dari jumlah seluruh siswa dapat mencapai nilai KKM yang ditentukan oleh sekolah yaitu 78 . Teknik analisis data yang digunakan adalah deskriptif kualitatif dan deskriptif kuantitatif dengan persentase.

Hasil penelitian menunjukkan bahwa Implementasi Strategi Pembelajaran Aktif Tipe Instant Assessment dapat meningkatkan Prestasi Belajar Kompetensi Dasar Mengelola Kartu Utang siswa kelas XI Akuntansi 2 SMK YAPEMDA 1 Sleman Tahun Ajaran 2017/2018. Keberhasilan tindakan tersebut dibuktikan dengan terjadinya peningkatan nilai rata-rata setelah tindakan (post test) I ke nilai rata-rata setelah tindakan (post test) II. Pada siklus I nilai rata-rata setelah tindakan (post test) sebesar 77,3 dan pada siklus II Sebesar 80,15. Secara keseluruhan kenaikan nilai rata-rata adalah sebesar 2,85 setelah adanya tindakan dengan dua siklus. Peningkatan juga terjadi pada jumlah siswa yang mencapai Kriteria Ketuntasan Minimal (KKM) yaitu pada siklus I jumlah siswa yang mencapai KKM sebesar $60 \%$ dan siklus II sebesar $85 \%$, sehingga secara keseluruhan kenaikan sebesar $25 \%$ setelah adanya tindakan dengan dua siklus.
\end{abstract}


Kata Kunci: Instant Assessment, Prestasi Belajar, Kartu Utang.

\section{Abstract}

This research aims to improve Learning Achievement of Managing Payable Card by Implementing Active Learning Strategy Type Instant Assessment on student of class XI Accounting 2 SMK YAPEMDA 1 Sleman in the academic year of 2017/2018.

This research is a classroom action research conducted in two cycles. Every cycle has been held in one class meeting. The steps of this research are planning, acting, observing and reflection. The subjects were 20 students of class XI Accounting 2 SMK YAPEMDA 1 Sleman. Indicator of success in this research are when student average score increase from post test cycle I to post test cycle II and 75\% from all of students reached Minimum Achievement Criteria which has been determined that is 78. The data analysis technique in this research are qualitative and quantitative descriptive by percentage.

Result of this research showed that implementation of Active Learning Strategy type Instant Assessment is able to improve Learning Achievement of Managing Payable Card on student of class XI Accounting 2 SMK YAPEMDA 1 Sleman in the academic year of 2017/2018. Implementation of Active Learning Strategy Type Instant Assessment is able to improve average score after research (post test) in cycle I to average score after research (post test) in cycle II. At cycle I average score after research (post test) is 77,3 and cycle II is 80,15. After the two cycle have been implemented, average score in a whole increase 2,85. Student reached Minimum Achievement Criteria also increase of equal to $60 \%$ in the first cycle and $85 \%$ in the second cycle, so that as whole increase of equal to $25 \%$ after research with two cycle.

Keywords: Instant Assessment, Learning Achievement, Managing Payable Card.

\section{PENDAHULUAN}

Pada pembukaan UUD 1945 menyatakan bahwa salah satu tujuan nasional Negara Indonesia adalah mencerdaskan kehidupan bangsa. Pendidikan berfungsi menghasilkan sumber daya manusia yang berkualitas, serta mencetak lulusan yang mampu mengamalkan ilmunya yang diperoleh dari pendidikan. Dalam mewujudkan tujuan tersebut salah satu cara yang dapat dilakukan adalah meningkatkan kualitas pendidikan, khususnya kualitas pembelajaran.

Pembelajaran yang berkualitas adalah pembelajaran yang melibatkan seluruh komponen utama proses belajar mengajar. Komponen utama tersebut yaitu guru, siswa dan interaksi antara keduanya. Peningkatan kualitas pembelajaran dapat dilihat dari meningkatnya prestasi belajar siswa. Prestasi belajar yang baik dapat menjadi indikator bahwa siswa mempunyai kemampuan dan keterampilan yang baik dalam bidang pelajaran, sebaliknya bagi siswa yang prestasi belajarnya kurang baik dapat menjadi indikator bahwa siswa belum memahami pelajaran tersebut. Prestasi belajar juga dipengaruhi oleh berbagai faktor, salah satunya adalah faktor guru.

Guru harus berkontribusi secara maksimal terkait dengan materi, media, maupun strategi pembelajaran yang digunakan. Terutama dalam memilih metode atau strategi pembelajaran, seorang guru harus mempertimbangkan keanekaragaman gaya belajar yang dimiliki setiap siswa sehingga tidak mengalami kesalahan dalam menerapkan strategi pembelajaran. Berdasarkan atas observasi di beberapa sekolah, kegiatan belajar mengajar yang terlaksana masih menggunakan model ceramah. Ceramah oleh guru juga tidak dapat mengukur kemampuan siswa dalam 
menangkap materi yang telah dijelaskan oleh guru tersebut.

Berdasarkan hasil observasi pada tanggal 12 Juni 2017 di SMK YAPEMDA 1 Sleman yang beralamat di Kalitirto, Berbah, Kabupaten Sleman, Daerah Istimewa Yogyakarta, siswa terlihat kurang memerhatikan materi yang disampaikan guru, bahkan ada siswa yang melakukan kegiatan lain yang tidak berhubungan dengan materi pembelajaran. Hal tersebut menyebabkan suasana di kelas menjadi kurang kondusif. Penyampaian materi ajar yang dilakukan guru masih menggunakan metode ceramah sehingga siswa cenderung bosan untuk mengikuti pelajaran Akuntansi Keuangan.

SMK YAPEMDA 1 Sleman merupakan salah satu sekolah swasta yang mempunyai program keahlian Akuntansi. Program keahlian Akuntansi di SMK YAPEMDA 1 Sleman masih menghadapi permasalahan yang berkaitan dengan prestasi belajar siswa. Berdasarkan dokumentasi daftar nilai siswa kelas XI Akuntansi 2 SMK YAPEMDA 1 Sleman Tahun Ajaran 2017/2018 mata pelajaran Akuntansi Keuangan yang terdiri atas nilai ulangan harian, tugas terstruktur, ujian tengah semester serta ujian akhir semester, di kelas XI Akuntansi 2 SMK YAPEMDA 1 Sleman Tahun Ajaran 2017/2018 terdapat 8 siswa dari 20 siswa yang belum memenuhi Kriteria Ketuntasan Minimal (KKM), dari yang seharusnya hanya ada maksimal 5 siswa yang belum memenuhi Kriteria Ketuntasan Minimal (KKM). Ini berarti masih $40 \%$ siswa yang belum memenuhi KKM yang telah ditetapkan oleh sekolah yaitu 78 .

Dokumentasi daftar nilai siswa kelas XI Akuntansi 2 SMK YAPEMDA 1 Sleman Tahun Ajaran 2016/2017 mata pelajaran Akuntansi Keuangan menunjukan bahwa terdapat 8 siswa dari 19 siswa yang belum memenuhi Kriteria Ketuntasan Minimal (KKM), dari yang seharusnya hanya ada maksimal 5 siswa yang belum memenuhi Kriteria Ketuntasan Minimal (KKM). Ini berarti masih $42 \%$ siswa yang belum memenuhi KKM. Dokumentasi daftar nilai siswa kelas XI Akuntansi 2 SMK YAPEMDA 1 Sleman Tahun Ajaran 2015/2016 mata pelajaran Akuntansi Keuangan juga menunjukkan bahwa terdapat 9 siswa dari 20 siswa yang belum memenuhi Kriteria Ketuntasan Minimal (KKM), dari yang seharusnya hanya ada maksimal 5 siswa yang belum memenuhi Kriteria Ketuntasan Minimal (KKM). Ini berarti masih $45 \%$ siswa yang belum memenuhi KKM. Depdikbud (2006) menjelaskan untuk ketuntasan pembelajaran klasikal, bahwa "Kelas dikatakan sudah tuntas secara klasikal jika telah mencapai $75 \%$ dari seluruh siswa memperoleh nilai Kriteria Ketuntasan Minimal".

Berdasarkan kegiatan observasi di kelas XI Akuntansi 2 SMK YAPEMDA 1 Sleman juga diketahui bahwa proses pelaksanaan pembelajaran di dalam kelas masih dilakukan dengan metode ceramah. Penggunaan metode mengajar tersebut masih monoton sehingga belum dapat mengoptimalkan potensi yang dimiliki oleh siswa. Hal tersebut menyebabkan siswa kurang dapat memahami materi pelajaran yang diberikan sehingga prestasi belajar yang dicapai masih rendah.

Siswa kelas XI Akuntansi 2 SMK YAPEMDA 1 Sleman Tahun Ajaran 2017/2018 memiliki kriteria yaitu keterlekatan pada tugas (commitment), tanggung jawab (responsibility) yang baik, motivasi (motivation) siswa juga baik. Strategi pembelajaran yang bersifat aktif dibutuhkan untuk meningkatkan prestasi belajar Akuntansi Keuangan siswa kelas XI Akuntansi 2 SMK YAPEMDA 1 Sleman Tahun Ajaran 2017/2018. Salah satu tipe strategi pembelajaran aktif adalah Instant Assessment. Strategi Pembelajaran Aktif Tipe Instant Assessment ini memiliki 5 prinsip yaitu: keterlekatan pada tugas (commitment), tanggung jawab (responsibility), motivasi (motivation), berorentasi pada tujuan dan aktivitas. Hal ini sesuai dengan kriteria siswa kelas XI Akuntansi 2 SMK YAPEMDA 1 Sleman 
Tahun Ajaran 2017/2018 sehingga Strategi Pembelajatan Aktif Instant Assessment dapat diterapkan di kelas tersebut.

Berdasarkan hasil observasi di kelas, guru Akuntansi Keuangan belum mampu menggunakan strategi yang dapat meningkatkan Prestasi Belajar Kompetensi Dasar Mengelola Kartu Utang ini, maka Strategi Pembelajaran Aktif Tipe Instant Assessment ini diharapkan mampu menjadi alternatif pemecahan masalah untuk mengatasi rendahnya Prestasi Belajar Kompetensi Dasar Mengelola Kartu Utang pada siswa kelas XI Akuntansi 2 SMK YAPEMDA 1 Sleman Tahun Ajaran 2017/2018. Berdasarkan uraian di atas, maka peneliti bermaksud melakukan penelitian yang berjudul "Implementasi Strategi Pembelajaran Aktif Tipe Instant Assessment untuk Meningkatkan Prestasi Belajar Kompetensi Dasar Mengelola Kartu Utang Siswa Kelas XI Akuntansi 2 SMK YAPEMDA 1 Sleman Tahun Ajaran 2017/2018".

\section{METODE PENELITIAN}

Penelitian yang dilakukan merupakan jenis penelitian tindakan kelas atau dikenal dalam Bahasa Inggris dengan istilah Classroom Action Research. Penelitian tindakan kelas merupakan suatu pencermatan terhadap kegiatan belajar berupa sebuah tindakan, yang sengaja dimunculkan dan terjadi dalam sebuah kelas secara.

Penelitian ini dilaksanakan di kelas XI Akuntansi 2 SMK YAPEMDA 1 Sleman Tahun Ajaran 2017/2018 dengan alamat Kalitirto, Berbah, Kabupaten Sleman, Daerah Istimewa Yogyakarta. Penelitian ini dilaksanakan pada bulan Januari hingga Februari 2018. Waktu penelitian termasuk waktu saat observasi dan pelaksanaan penelitian.

Subjek dalam penelitian ini adalah Siswa Kelas XI Akuntansi 2 SMK YAPEMDA 1 Sleman Tahun Ajaran 2017/2018 yang berjumlah 20 siswa. Objek penelitian ini adalah Prestasi Belajar Akuntansi Kompetensi Dasar Mengelola Kartu Utang
Siswa Kelas XI Akuntansi 2 SMK YAPEMDA 1 Sleman Tahun Ajaran 2017/2018.

\section{Instrumen Penelitian}

Instrumen penelitian yang digunakan adalah pedoman observasi, catatan lapangan dan tes. Pedoman observasi untuk mengetahui pelaksanaan pembelajaran, penggunaan teknik pembelajaran, dan kesesuaiannya dengan rencana pembelajaran yang telah dirancang. Catatan lapangan berupa formulir yang digunakan sebagai pencatat berita acara pelaksanaan Strategi Pembelajaran Aktif Tipe Instant Assessment. Tes digunakan sebagai penggerak dalam Strategi Pembelajaran Aktif Tipe Instant Assessment dan sebagai evaluasi terhadap pemahaman siswa terhadap materi yang sudah disampaikan oleh guru maupun peneliti. Tes prestasi dalam penelitian ini dilakukan dengan pemberian soal sebelum tindakan (pre test) dan soal setelah tindakan (post test) pada tiap akhir siklusnya.

\section{Teknik Analisis Data}

Teknik analisis data yang digunakan dalam penelitian ini adalah analisis data deskriptif kuantitatif berupa nilai dari pencapaian Prestasi Belajar Akuntansi Kompetensi Dasar Mengelola Kartu Utang dan teknik analisis data kualitatif yang dilakukan pada saat pengumpulan data dalam periode tertentu.

\section{Prosedur Penelitian}

Pelaksanaan penelitian ini akan berkolaborasi dengan guru mata pelajaran Akuntansi Keuangan di SMK Yapemda 1 Sleman pokok bahasan pengelolaan kartu utang yang mengampu siswa kelas XI Akuntansi 2 SMK Yapemda 1 Sleman Tahun Ajaran 2017/2018. Penelitian ini direncanakan dalam dua siklus, akan tetapi akan dilanjutkan pada siklus berikutnya apabila hasil dalam penelitian ini belum memenuhi indikator keberhasilan yang telah ditetapkan sebelumnya. Pelaksanaan penelitian akan berakhir ketika hasil 
penelitian telah mencapai indikator keberhasilan yang telah ditetapkan. Indikator keberhasilan tersebut yaitu apabila $75 \%$ siswa telah berhasil mencapai nilai KKM untuk mata pelajaran Akuntansi Keuangan yaitu sebesar 78. Setiap siklus terdiri dari empat tahap, yaitu: perencanaan tindakan, pelaksanakan tindakan, observasi dan interpretasi, dan analisis dan refleksi.

\section{Indikator Keberhasilan}

Indikator keberhasilan penelitian ini dengan penerapan Strategi Pembelajaran Aktif Tipe Instant Assessment adalah meningkatnya Prestasi Belajar Kompetensi Dasar Mengelola Kartu Utang didasarkan pada peningkatan nilai rata-rata kelas dari siklus I ke siklus II dan minimal $75 \%$ dari jumlah siswa dalam satu kelas atau minimal 15 siswa mencapai Kriteria Ketuntasan Minimal (KKM) yang telah ditentukan sekolah yaitu 78. KKM ditetapkan oleh sekolah pada awal tahun pelajaran dengan memperhatikan: intake (kemampuan rata-rata peserta didik), kompleksitas (mengidentifikasi indikator sebagai penanda tercapainya kompetensi dasar), dan kemampuan daya pendukung (berorientasi pada sumber belajar).

\section{HASIL PENELITIAN DAN PEMBAHASAN \\ Perencanaan Strategi Pembelajaran Aktif Tipe Instant Assessment}

Pertimbangan yang dilakukan oleh peneliti dalam memilih strategi pembelajaran adalah kesesuaian antara strategi pembelajaran yang akan diimplementasikan dengan karakteristik siswa kelas XI Akuntansi 2 SMK YAPEMDA 1 Sleman. Berdasarkan hasil observasi, diketahui bahwa karakteristik siswa kelas XI Akuntansi 2 SMK YAPEMDA 1 Sleman adalah siswa memiliki keterlekatan pada tugas (commitment). Siswa kelas XI Akuntansi 2 SMK YAPEMDA 1 Sleman Tahun Ajaran 2017/2018 juga memiliki tanggung jawab (responsibility) yang baik.
Motivasi (motivation) siswa juga baik. Siswa aktif mencari, menemukan, dan memecahkan masalahnya sendiri. Guru dan siswa juga berorientasi pada tujuan, yaitu tercapainya tujuan pembelajaran yang telah ditetapkan serta memiliki aktivitas pembelajaran berupa pengerjaan tugas dan latihan soal yang dapat mendorong siswa untuk memecahkan masalah secara mandiri. Pertimbangan lainnya dalam pemilihan strategi pembelajaran adalah tindakan yang dilakukan oleh guru dalam proses pembelajaran. Guru selalu memberikan latihan soal dan tugas dalam proses pembelajaran untuk melatih kemampuan berfikir siswa.

Berdasarkan atas beberapa pertimbangan di atas, maka peneliti memilih Strategi Pembelajaran Aktif Tipe Instant Assessment. Strategi Pembelajaran Aktif Tipe Instant Assessment ini memiliki 5 prinsip yaitu: keterlekatan pada tugas (commitment), tanggung jawab (responsibility), motivasi (motivation), berorentasi pada tujuan dan aktivitas. Hal ini sesuai dengan kriteria siswa kelas XI Akuntansi 2 SMK YAPEMDA 1 Sleman Tahun Ajaran 2017/2018 sehingga Strategi Pembelajatan Aktif Instant Assessment dapat diterapkan di kelas tersebut.

Berdasarkan atas hasil observasi, diskusi serta pertimbangan waktu pelaksanaan penelitian, maka ditentukan materi yang akan dikaji dalam penelitian ini adalah prosedur pengelolaan kartu utang, peralatan dan dokumen yang dibutuhkan untuk pengelolaan utang, dokumen mutasi utang dan prosedur pencatatan mutasi utang. Peneliti kemudian berdiskusi bersama guru mengenai Rencana Pelaksanaan Pembelajaran (RPP) dengan Strategi Pembelajaran Aktif Tipe Instant Assessment yang akan dilaksanakan di kelas XI Akuntansi 2 SMK YAPEMDA 1 Sleman.

\section{Penyusunan Rancangan Tindakan Pelaksanaan Strategi Pembelajaran Aktif Tipe Instant Assessment}


Peneliti melakukan diskusi dengan guru mata pelajaran Akuntansi Keuangan, disepakati bahwa guru berperan sebagai pemberi informasi dan fasilitator selama proses kegiatan pembelajaran sedangkan peneliti dan guru secara bersama-sama bertugas mengamati kegiatan siswa selama proses pembelajaran. Penelitian ini rencananya akan dilaksanakan dalam 2 siklus sampai tujuan dari penelitian ini tercapai, dimana tujuan dari penelitian ini adalah meningkatkan Prestasi Belajar Kompetensi Dasar Mengelola Kartu Utang. Apabila telah terjadi peningkatan Prestasi Belajar Kompetensi Dasar Mengelola Kartu Utang maka penelitian ini akan dihentikan. Strategi Pembelajaran Aktif Tipe Instant Assessment ini memiliki 5 prinsip yaitu: keterlekatan pada tugas (commitment), tanggung jawab (responsibility), motivasi (motivation), berorentasi pada tujuan dan aktivitas. Kelima prinsip dari Strategi Pembelajaran Aktif Tipe Instant Assessment akan dimunculkan dalam setiap langkah penelitian tindakan kelas ini.

Siklus I meliputi langkah: perencanaan tindakan (planning), pelaksanaan tindakan, pengamatan tindakan dan refleksi tindakan. Setiap langkah dalam siklus I dibuat dengan memerhatikan 5 prinsip dari Strategi Pembelajaran Aktif Tipe Instant Assessment. Perencanaan tindakan siklus I terdiri atas menentukan kompetensi dasar, menyusun Rencana Pelaksanaan Pembelajaran (RPP), menyiapkan sumber belajar, menyusun instrumen penelitian tes serta membuat catatan lapangan. Pada langkah perencanaan tindakan siklus I, materi yang dipilih harus memberikan kebermanfaatan (meaningful), sesuai dengan kebutuhan siswa (relevant) serta memiliki keterkaitan dengan pribadi (personal) siswa program keahlian Akuntansi. Siswa juga diajarkan untuk bertanggung jawab melalui pertanyaan yang akan diberikan oleh guru. Motivasi belajar serta berorientasi pada tujuan juga akan ditumbuhkan dalam pembelajaran dengan menggunakan Strategi Pembelajaran Aktif Tipe Instant Assessment.
Tahap pelaksanaan tindakan merupakan bentuk pelaksanaan dari perencanaan yang telah dibuat. Tahap pelaksanaan tindakan meliputi: kegiatan pembelajaran awal, kegiatan pembelajaran inti dan kegiatan penutup. Dalam setiap kegiatan pembelajaran 5 prinsip Strategi Pembelajaran Aktif Tipe Instant Assessment menjadi hal yang terpenting untuk dilaksanakan. Pengamatan pada siklus I dilakukan dengan mengamati guru, siswa serta Prestasi Belajar Kompetensi Dasar Mengelola Kartu Utang. Peneliti juga akan mengamati apakah 5 prinsip Strategi Pembelajaran Aktif Tipe Instant Assessment: keterlekatan pada tugas (commitment), tanggung jawab (responsibility), motivasi (motivation), berorentasi pada tujuan dan aktivitas sudah dilaksanakan dengan baik atau belum. Peneliti selanjutnya melakukan refleksi atas pelaksanaan siklus I.

Penyusunan rancangan tindakan pada siklus II pada dasarnya sama dengan rancangan tindakan pada siklus I, namun mengalami perbaikan berdasarkan atas hasil refleksi pada siklus I. Siklus II terdiri dari 4 langkah, yaitu: perencanaan tindakan (planning), pelaksanaan tindakan, pengamatan tindakan dan refleksi tindakan. Setiap langkah dalam siklus II dibuat dengan mempertimbangkan 5 prinsip dari Strategi Pembelajaran Aktif Tipe Instant Assessment.

\section{Deskripsi Hasil Penelitian}

\section{Laporan Siklus 1}

Kegiatan pembelajaran kompetensi dasar mengelola kartu utang dengan Strategi Pembelajaran Aktf Tipe Instant Assessment pada siklus I dilakukan 1 kali pertemuan yaitu pada hari Kamis, 15 Februari 2018 pada jam ke-5 dan ke-6. Materi yang disampaikan pada siklus I terdiri dari 2 materi pokok, yaitu prosedur pengelolaan kartu utang serta peralatan dan dokumen yang dibutuhkan untuk pengelolaan kartu utang. Berikut ini tahap - tahap dalam melaksanakan tindakan siklus I.

a. Perencanaan Tindakan (Planing) 
Langkah - langkah yang ditempuh dalam tahap perencanaan yaitu menentukan kompetensi dasar yang akan dijadikan materi bahasan pada penelitian, menyusun atau membuat Rencana Pelaksanaan Pembelajaran (RPP) dengan menggunakan Strategi Pembelajaran Aktif Tipe Instant Assessment, menyiapkan sumber belajar yang berupa ringkasan materi mengelola katu utang, menyusun instrumen penelitian, yang berupa tes, dan menyiapkan lembar catatan lapangan.

b. Pelaksanaan Tindakan

Pelaksanaan tindakan dalam penelitian ini meliputi kegiatan pembelajaran awal (15 menit), kegiatan inti (60 menit), dan kegiatan akhir (15 menit).

c. Pengamatan Tindakan

Pengamatan yang dilakukan yaitu pengamatan terhadap guru, pengamatan terhadap siswa, dan pengamatan terhadap prestasi belajar kompetensi dasar Mengelola Kartu Utang.

Berdasarkan atas dokumentasi daftar nilai Prestasi Belajar Kompetensi Dasar Mengelola Kartu Utang Siklus I juga dapat diketahui bahwa nilai rata-rata tes sebelum tindakan (pre test) adalah 61 . Perhitungan nilai rata-rata tes sebelum tindakan (pre test) adalah sebagai berikut:

$M e=\frac{\Sigma X i}{N}$

Rata-rata pre test $=\frac{\Sigma X i}{N}=\frac{1.220}{20}=61$

Persentase siswa yang mencapai KKM berdasarkan atas nilai tes sebelum tindakan (pre test) adalah 20\%, perhitungannya adalah sebagai berikut: $\mathrm{KB}=\frac{T}{T t} \times 100 \%$

Persentase ketuntasan siswa pada pre test $=\frac{T}{T t} \times 100 \%=\frac{4}{20} \times 100 \%=20 \%$

Dokumentasi daftar nilai Prestasi Belajar Kompetensi Dasar Mengelola Kartu Utang Siklus I juga dapat diketahui bahwa nilai rata-rata tes setelah tindakan (post test) adalah 77,3. Perhitungan nilai rata-rata tes setelah tindakan (post test) adalah sebagai berikut:

$M e=\frac{\Sigma X i}{N}$

Rata-rata post test $=\frac{\Sigma X i}{N}=\frac{1546}{20}=77,3$

Persentase siswa yang mencapai KKM berdasarkan atas nilai tes setelah tindakan (post test) adalah 60\%, perhitungannya adalah sebagai berikut: $\mathrm{KB}=\frac{T}{T t} \times 100 \%$

Persentase ketuntasan siswa pada post test $=\frac{T}{T t} \times 100 \%=\frac{12}{20} \times 100 \%=60 \%$.

Penelitian yang dilakukan dengan menggunakan Strategi Pembelajaran Aktif Tipe Instant Assessment pada siklus I ini dapat meningkatkan persentase siswa yang telah mencapai KKM dari sebelum adanya tindakan dibandingkan dengan setelah adanya tindakan. Siklus I telah menunjukkan adanya peningkatan pada persentase ketuntasan siswa yang telah mencapai $\mathrm{KKM}$, namun persentase siswa yang telah mencapai KKM belum mencapai indikator keberhasilan tindakan yaitu $75 \%$, oleh karena itu penelitian dilanjutkan pada siklus selanjutnya yaitu siklus II.

d. Refleksi Tindakan

Refleksi diadakan setelah kegiatan pelaksanaan penelitian selesai. Refleksi pada siklus pertama dilakukan dengan mengkaji hasil pengamatan selama kegiatan pembelajaran berlangsung. Dari kegiatan refleksi dapat diketahui permasalahan atau kendala yang dihadapi serta kelebihan dari implementasi Strategi Pembelajaran Aktif Tipe Instant Assessment.

2. Laporan Siklus 2

Kegiatan pembelajaran kompetensi dasar mengelola kartu utang dengan Strategi Pembelajaran Aktf Tipe Instant 
Assessment pada siklus II dilakukan 1 kali pertemuan yaitu pada hari Selasa, 20 Februari 2018 pada jam ke-5 dan ke-6. Materi yang disampaikan pada siklus I terdiri dari 2 materi pokok, yaitu prosedur pengelolaan kartu utang serta peralatan dan dokumen yang dibutuhkan untuk pengelolaan kartu utang. Berikut ini tahap-tahap dalam melaksanakan tindakan siklus II:

a. Secara prosedural tahap perencanaan pada siklus II sama dengan siklus I, akan tetapi perencanaan tindakan untuk siklus II dilakukan dengan perbaikan berdasarkan kegiatan refleksi siklus I.

b. Pelaksanaan tindakan ini meliputi kegiatan pembelajaran awal (15 menit), kegiatan inti (60 menit), dan kegiatan akhir (15 menit).

c. Pengamatan tindakan yang dilakukan yaitu pengamatan terhadap guru, pengamatan terhadap siswa, dan pengamatan terhadap prestasi belajar kompetensi dasar Mengelola Kartu Utang.

Berdasarkan atas dokumentasi daftar nilai Prestasi Belajar Kompetensi Dasar Mengelola Kartu Utang Siklus II dapat diketahui bahwa nilai rata-rata tes sebelum tindakan (pre test) adalah 63,05. Perhitungan nilai rata-rata tes sebelum tindakan (pre test) adalah sebagai berikut:

$$
M e=\frac{\Sigma X i}{N}
$$

Rata-rata pre test $=\frac{\Sigma X i}{N}=\frac{1216}{20}=63,05$

Persentase siswa yang mencapai KKM berdasarkan atas nilai tes sebelum tindakan (pre test) adalah 20\%, perhitungannya adalah sebagai berikut:

$\mathrm{KB}=\frac{T}{T t} \times 100 \%$

Persentase ketuntasan siswa pada pre test $=\frac{T}{T t} \times 100 \%=\frac{4}{20} \times 100 \%=20 \%$

Dokumentasi daftar nilai Prestasi Belajar Kompetensi Dasar Mengelola Kartu Utang Siklus II juga dapat diketahui bahwa nilai rata-rata tes setelah tindakan (post test) adalah 80,15 . Perhitungan nilai rata-rata tes setelah tindakan (post test) adalah sebagai berikut:

$M e=\frac{\Sigma X i}{N}$

Rata-rata post test $=\frac{\Sigma X i}{N}=\frac{1603}{20}=80,15$

Persentase siswa yang mencapai KKM berdasarkan atas nilai tes setelah tindakan (post test) adalah 85\%, perhitungannya adalah sebagai berikut: $\mathrm{KB}=\frac{T}{T t} \times 100 \%$

Persentase ketuntasan siswa pada post test siklus $\mathrm{II}=\frac{T}{T t} \times 100 \%=\frac{17}{20} \times 100 \%$ $=85 \%$

Penelitian yang dilakukan dengan menggunakan Strategi Pembelajaran Aktif Tipe Instant Assessment pada siklus II ini dapat meningkatkan nilai rata-rata dan persentase siswa yang telah mencapai KKM dari siklus I. Siklus II telah menunjukkan adanya peningkatan pada nilai rata-rata siswa dan presentase ketuntasan siswa yang telah mencapai KKM, dan telah mencapai indikator keberhasilan yang telah ditentukan yaitu siswa yang mencapi KKM minimal 75\%.

d. Refleksi Tindakan

Prinsip Strategi Pembelajaran Aktif Tipe Instant Assessment juga sudah dapat dilaksanakan dalam tahapan pembelajaran. Materi yang diberikan oleh guru kepada siswa memiliki kebermanfaatan (meaningful), sesuai dengan kebutuhan siswa (relevant) serta memiliki keterkaitan pribadi (personal) dengan siswa program Akuntansi.

e. Proses pembelajaran pada siklus II secara umum telah dilaksanakan sesuai dengan perencanaan. Hasil tes pada siklus II menunjukkan bahwa Prestasi Belajar Kompetensi Mengelola Kartu Utang telah mengalami peningkatan dibandingkan hasil tes pada siklus I. 
Jumlah siswa yang mencapai KKM pada siklus II juga telah meningkat dibandingkan pada siklus I. Pada siklus II ini, persentase jumlah siswa yang telah mencapai KKM yaitu sebanyak $85 \%$ atau telah melebihi indikator keberhasilan peneliti. Oleh karena itu, penelitian tindakan kelas dengan implementasi Strategi Pembelajaran Aktif Tipe Instant Assessment pada Siswa Kelas XI Akuntansi 2 SMK YAPEMDA 1 Sleman diakhiri pada siklus II.

\section{Pembahasan Hasil Penelitian}

1. Pembahasan Hasil Penelitian Siklus I

Perencanaan tindakan siklus I terdiri atas menentukan kompetensi dasar, menyusun Rencana Pelaksanaan Pembelajaran (RPP), menyiapkan sumber belajar, menyusun instrumen penelitian tes serta membuat catatan lapangan. Pada langkah perencanaan tindakan siklus I, materi yang dipilih harus memberikan kebermanfaatan (meaningful), sesuai dengan kebutuhan siswa (relevant) serta memiliki keterkaitan dengan pribadi (personal) siswa program keahlian Akunta nsi. Kebermanfaatan (meaningful) bagi siswa adalah siswa dapat mengetahui tingkat resiko yang berkaitan dengan pinjaman atau kredit yang akan diberikan, selain itu materi mengelola kartu utang merupakan materi yang berkaitan dengan kehidupan sehari-hari (relevant), siswa dapat memahami bagaimana cara mengelola utang dengan baik sehingga siswa dapat mengelola dan mengendalikan keuangan pribadi (personal). Materi yang dipelajari juga berguna untuk melancarkan kehidupan pada bidang ekonomi serta memantapkan kelangsungan hidup. Hal ini sesuai dengan teori yang dijelaskan oleh Zairani Zainal dkk (2016:304) "Utang adalah kewajiban yang harus dibayarkan oleh individu."
Siswa juga diajarkan untuk bertanggung jawab melalui pertanyaan yang diberikan oleh guru. Tanggung jawab disini adalah siswa dapat memberikan alasan memilih jawaban atas pertanyaan yang diajukan oleh guru. Motivasi belajar serta berorientasi pada tujuan juga ditumbuhkan dalam pembelajaran dengan menggunakan Strategi Pembelajaran Aktif Tipe Instant Assessment. Proses pembelajaran yang telah dilaksanakan mengedepankan pada aktivitas siswa. Motivasi belajar ditumbuhkan setelah siswa mengetahui tujuan pembelajaran apa yang akan dicapai, sehingga aktivitas siswa dalam pembelajaran juga akan tinggi. Hal ini sesuai dengan teori yang disampaikan oleh Rusman (2010: 324) "Pembelajaran aktif merupakan pendekatan pembelajaran yang lebih banyak melibatkan aktivitas siswa dalam mengakses berbagai informasi dan pengetahuan untuk dibahas dan dikaji dalam proses pembelajaran di kelas, sehingga mereka mendapatkan berbagai pengalaman yang dapat meningkatkan pemahaman dan kompetensinya."

Pelaksanaan tindakan pada siklus I meliputi: kegiatan pembelajaran awal, kegiatan pembelajaran inti dan kegiatan penutup. Dalam setiap kegiatan pembelajaran 5 prinsip Strategi Pembelajaran Aktif Tipe Instant Assessment menjadi hal yang terpenting untuk dilaksanakan. Pada tahap pelaksanaan, siswa diharuskan untuk memiliki orientasi pada tujuan setelah mengetahui tujuan pembelajaran yang disampaikan oleh guru. Materi pembelajaran yang disampaikan telah dipertimbangkan berdasarkan adanya kebermanfaatan (meaningful), sesuai dengan kebutuhan siswa (relevant) serta memiliki keterkaitan dengan pribadi (personal) siswa program keahlian Akuntansi. Siswa diajarkan bahwa materi yang dipelajari berkaitan dengan kehidupan sehari-hari, karena utang 
merupakan hal yang tidak terpisahkan dari pengelolaan keuangan, baik pengelolaan secara individu (personal) maupun pengelolaan keuangan pada dunia kerja. Pada tahap pelaksanaan, guru memberikan pertanyaan dan tes yang menuntut tanggung jawab siswa serta motivasi siswa untuk memahami materi yang diberikan oleh guru. Siswa diajarkan bagaimana bertanggung jawab terhadap keputusan yang diambilnya serta dapat memberikan alasan mengenai jawaban tersebut. Kegiatan pembelajaran yang telah dilaksanakan dominan kepada siswa sehingga aktivitas siswa dalam pembelajaran tinggi.

Pengamatan tindakan pada siklus I dilakukan dengan mengamati guru, siswa serta Prestasi Belajar Kompetensi Dasar Mengelola Kartu Utang. Peneliti mengamati apakah guru dan siswa melaksanakan proses pembelajaran sesuai dengan yang telah ditentukkan atau belum. Pada siklus I ini, guru sudah melaksanakan pembelajaran dengan Strategi Pembelajaran Aktif Tipe Instant Assessment dengan baik, namun guru masih bingung dengan alur pembelajaran. Aktivitas siswa sudah tinggi dalam pembelajaran, siswa memiliki motivasi belajar yang baik ketika mengikuti proses pembelajaran. Prestasi Belajar Kompetensi Dasar Mengelola Kartu Utang siswa kelas XI Akuntansi 2 SMK YAPEMDA 1 Sleman juga mengalami peningkatan.

Pada siklus I nilai rata-rata siswa sebelum tindakan (pre test) adalah 61, sedangkan nilai rata-rata setelah tindakan (post test) adalah 77,3. Hal ini menunjukkan bahwa telah terjadi peningkatan nilai rata-rata siswa yaitu sebesar 16,3. Dilihat dari ketuntasan Prestasi Belajar Kompetensi Dasar Mengelola Kartu Utang, hasil tes sebelum ada tindakan (pre test) siswa yang mencapai KKM sebanyak 4 siswa atau $20 \%$ siswa, sedangkan setelah ada tindakan (post test) sudah ada 12 siswa atau $60 \%$ siswa telah mencapai KKM.

Setelah diadakan pengamatan terhadap pelaksanaan Strategi Pembelajaran Aktif Tipe Instant Assessment, peneliti kemudian melakukan refleksi tindakan. Refleksi pada siklus I dilakukan dengan mengkaji hasil pengamatan selama kegiatan pembelajaran berlangsung. Hasil refleksi menunjukkan bahwa guru sudah mampu untuk melaksanakan Strategi Pembelajaran Aktif Tipe Instant Assessment, namun guru belum sepenuhnya melaksanakan pembelajaran pada kompetensi dasar mengelola kartu utang dengan menggunakan Strategi Pembelajaran Aktif Tipe Instant Assessment.

Hasil post test pada siklus I menunjukkan 12 siswa atau $60 \%$ siswa sudah mencapai KKM yang ditetapkan oleh sekolah yaitu 78, akan tetapi belum mencapai indikator keberhasilan yang telah ditetapkan sesuai dengan teori dari Mulyasa (2016:183) "Pembelajaran dikatakan berhasil dan berkualitas apabila seluruhnya atau sebagian besar (75\%) siswa mampu menguasai suatu pelajaran".

2. Pembahasan Hasil Penelitian Siklus II

Pada siklus II, penyusunan rancangan tindakan pada dasarnya sama dengan rancangan tindakan pada siklus I, namun mengalami perbaikan berdasarkan atas hasil refleksi pada siklus I. Perencanaan tindakan pada siklus II terdiri atas: pemilihan materi pembelajaran, menyusun Rencana Pelaksanaan Pembelajaran (RPP), menyiapkan sumber belajar, menyusun instrumen penelitian dan menyiapkan lembar catatan lapangan. Materi yang dipilih pada siklus II dipertimbangkan berdasarkan atas kebermanfaatan bagi siswa (meaningful), sesuai dengan kebutuhan siswa (relevant), memiliki keterkaitan pribadi (personal), maka dipilihlah materi mengenai dokumentasi 
mutasi utang dan prosedur pencatatan mutasi utang. Materi mengenai dokumentasi mutasi utang dan prosedur pencatatan mutasi utang ini dinilai memiliki manfaat bagi siswa baik secara pribadi maupun dalam dunia kerja. Secara pribadi, siswa akan mengerti bagaimana prosedur pencatatan mutasi utang serta dokumen yang dibutuhkan. Siswa dapat mengelola keuangan pribadi, siswa juga dapat belajar mengenai mengelola keuangan perusahaan di dunia kerja. Menurut teori dari Hendi Somantri 2005: 169) "Dalam perusahaan yang menyelenggarakan buku besar pembantu utang, kartu utang berfungsi sebagai tempat mencatat transaksi utang pada setiap kreditor." Materi dokumentasi mutasi utang dan prosedur pencatatan mutasi utang ini juga merupakan kelanjutan dari materi pada siklus I, sehingga materi siklus I dan materi siklus II saling berkaitan.

Pelaksanaan pembelajaran dengan menggunakan Strategi Pembelajaran Aktif Tipe Instant Assessment kegiatan pembelajaran awal, kegiatan pembelajaran inti dan kegiatan penutup. Pada tahap pelaksanaan, siswa diharuskan untuk memiliki orientasi pada tujuan setelah mengetahui tujuan pembelajaran yang disampaikan oleh guru. Materi pembelajaran yang disampaikan telah dipertimbangkan berdasarkan adanya kebermanfaatan (meaningful), sesuai dengan kebutuhan siswa (relevant) serta memiliki keterkaitan dengan pribadi (personal) siswa program keahlian Akuntansi. Siswa diajakan bahwa materi yang dipelajari berkaitan dengan kehidupan sehari-hari, karena utang merupakan hal yang tidak terpisahkan dari pengelolaan keuangan, baik pengelolaan secara individu (personal) maupun pengelolaan keuangan pada dunia kerja. Pada tahap pelaksanaan, guru memberikan pertanyaan dan tes yang menuntut tanggung jawab siswa serta motivasi siswa untuk memahami materi yang diberikan oleh guru. Siswa diajarkan bagaimana bertanggung jawab terhadap keputusan yang diambilnya serta dapat memberikan alasan mengenai jawaban tersebut. Kegiatan pembelajaran yang telah dilaksanakan dominan kepada siswa sehingga aktivitas siswa dalam pembelajaran tinggi.

Peneliti dan guru berusaha untuk mengurangi metode ceramah seperti yang dilakukan pada proses pembelajaran sebelumnya, sehingga ketergantungan siswa terhadap penjelasan materi dari guru semakin berkurang dan siswa menemukan konsep materi melalui pembelajaran yang dilakukan. Silberman (2016:93) mengungkapkan bahwa "Melalui pertanyaan-pertanyaan atau tantangan pada Strategi Pembelajaran Aktif Tipe Instant Assessment ini, diharapkan dapat melatih siswa untuk berpikir secara cepat, juga melatih siswa untuk mengemukakan pendapat mengenai suatu masalah yang terjadi". Oleh karena itu, siswa diharapkan dapat mengembangkan cara berpikir dan keterampilan yang lebih tinggi. Implementasi Strategi Pembelajaran Aktif Tipe Instant Assessment menghadapkan siswa pada pertanyaanpertanyaan atau tantangan sehingga mereka termotivasi untuk mencari jawaban atas pertanyaan atau tantangan yang diberikan. Peningkatan kemampuan berpikir ini akan membuat siswa lebih percaya diri akan kemampuannya dan membuat siswa lebih aktif dalam proses pembelajaran sehingga Prestasi Belajar Kompetensi Dasar Mengelola Kartu Utang siswa kelas XI Akuntansi 2 SMK YAPEMDA 1 Sleman dapat meningkat.

Pengamatan tindakan pada siklus II dilakukan dengan mengamati guru, siswa serta Prestasi Belajar Kompetensi Dasar Mengelola Kartu Utang. Peneliti mengamati apakah guru dan siswa 
melaksanakan proses pembelajaran sesuai dengan yang telah ditentukkan atau belum. Pada siklus II ini, guru sudah melaksanakan pembelajaran dengan Strategi Pembelajaran Aktif Tipe Instant Assessment dengan baik, guru lebih memperhatikan RPP. Aktivitas siswa sudah tinggi dalam pembelajaran, siswa memiliki motivasi belajar yang baik ketika mengikuti proses pembelajaran. Prestasi Belajar Kompetensi Dasar Mengelola Kartu Utang siswa kelas XI Akuntansi 2 SMK YAPEMDA 1 Sleman juga mengalami peningkatan.

Pada siklus II nilai rata-rata siswa sebelum tindakan (pre test) adalah 63,05 , sedangkan nilai rata-rata setelah tindakan (post test) adalah 80,15. Hal ini menunjukkan bahwa telah terjadi peningkatan nilai rata-rata siswa yaitu sebesar 17,1. Dilihat dari ketuntasan Prestasi Belajar Kompetensi Dasar Mengelola Kartu Utang, sebelum ada tindakan (pre test) siswa yang mencapai KKM sebanyak 4 siswa atau $20 \%$ siswa, sedangkan setelah ada tindakan (post test) sudah ada 17 siswa atau $85 \%$ siswa telah mencapai. Hal ini menunjukkan bahwa telah terjadi peningkatan siswa yang telah mencapai KKM jika dibandingkan pada siklus I yang hanyak sebanyak 12 siswa atau $60 \%$ siswa yang mencapai KKM. Peningkatan Prestasi Belajar Kompetensi Dasar Mengelola Kartu Utang siklus I ke siklus II sebesar $25 \%$.

Hasil penelitian ini diperkuat oleh teori para ahli. Silberman mengemukakan bahwa (2016:93) Strategi Pembelajaran Aktif Tipe Instant Assessment merupakan suatu pendekatan dalam proses pembelajaran guna mengetahui kemampuan peserta didik secara cepat, kemudian untuk merangsang pengetahuan peserta didik tentang materi pelajaran. Strategi Pembelajaran Aktif Tipe Instant Assessment ini memiliki beberapa keunggulan diantaranya: 1) meningkatkan prestasi belajar siswa, 2) meninjau kelebihan dan kelemahan siswa dalam belajar, 3) memonitor kemajuan siswa, 4) menentukan jenjang kemampuan siswa, 4) menentukan efektifitas pembelajaran. Hal ini sesuai dengan hasil pada penelitian ini yang menunjukkan adanya peningkatan Prestasi Belajar Kompetensi Dasar Mengelola Kartu Utang siswa kelas XI Akuntansi 2 SMK YAPEMDA 1 Sleman Tahun Ajaran 2017/2018 setelah adanya Implementasi Strategi Pembelajaran Aktif Tipe Instant Assessment.

Berdasarkan data peningkatan Prestasi Belajar Kompetensi Dasar Mengelola Kartu Utang yang telah dijabarkan, dapat diketahui bahwa indikator keberhasilan dalam penelitian ini telah dicapai. Ketercapaian indikator keberhasilan penelitian ini ditunjukkan dengan jumlah siswa yang telah mencapai KKM telah melebihi $75 \%$ siswa di dalam kelas yaitu $85 \%$. Hal ini sesuai dengan pendapat dari Mulyasa (2016:183) "Pembelajaran dikatakan berhasil dan berkualitas apabila seluruhnya atau sebagian besar (75\%) siswa mampu menguasai suatu pelajaran". Indikator keberhasilan lain dalam penelitian ini juga telah tercapai, ditunjukkan dengan adanya peningkatan nilai rata-rata yang dicapai siswa, baik peningkatan nilai rata-rata dari sebelum tindakan/pre test menuju setelah tindakan/post test pada setiap siklus maupun peningkatan nilai rata-rata dari tes setelah tindakan/post test pada siklus pertama ke tes setelah tindakan/post test siklus kedua.

Hasil ini menunjukkan bahwa implementasi Strategi Pembelajaran Aktif Tipe Instant Assessment dapat meningkatkan Prestasi Belajar Kompetensi Dasar Mengelola Kartu Utang siswa kelas XI Akuntansi 2 SMK YAPEMDA 1 Sleman Tahun Ajaran 
2017/2018. Implementasi Strategi Pembelajaran Aktif Tipe Instant Assessment untuk meningkatkan Prestasi Belajar Kompetensi Dasar Mengelola Kartu Utang siswa kelas XI Akuntansi 2 SMK YAPEMDA 1 Sleman Tahun Ajaran 2017/2018 ini memberikan implikasi bahwa dengan adanya perubahan dan perbaikan strategi mengajar guru, Prestasi Belajar Kompetensi Dasar Mengelola Kartu Utang dapat meningkat. Pelaksanaan pembelajaran dengan implementasi Strategi Pembelajaran Aktif Tipe Instant Assessment ini dapat mengatasi permasalahan yang terjadi pada kelas XI Akuntansi 2 SMK YAPEMDA 1 Sleman Tahun Ajaran 2017/2018, yaitu rendahnya prestasi belajar Akuntansi Keuangan pada kompetensi dasar mengelola kartu utang, oleh karena itu usaha perubahan dan perbaikan di dalam proses pembelajaran perlu untuk dilakukan secara terus menerus. Strategi Pembelajaran Aktif Tipe Instant Assessment ini dapat diimplementasi kembali pada mata pelajaran Akuntansi Keuangan kompetensi dasar mengelola kartu utang dengan modifikasimodifikasi lain maupun tidak.

\section{SIMPULAN DAN SARAN Simpulan}

Berdasarkan hasil penelitian dan pembahasan yang telah dilakukan pada bab sebelumnya, dapat disimpulkan bahwa implementasi Strategi Pembelajaran Aktif Tipe Instant Assessment dapat meningkatkan Prestasi Belajar Kompetensi Dasar Mengelola Kartu Utang Siswa Kelas XI Akuntansi 2 SMK YAPEMDA 1 Sleman Tahun Ajaran 2017/2018. Prestasi Belajar Kompetensi Dasar Mengelola Kartu Utang ini dapat dijabarkan sebagai berikut:

a. Pada siklus I nilai rata-rata setelah adanya tindakan (post test) adalah sebesar 77,3. Pada siklus II nilai rata-rata setelah adanya tindakan (post test) adalah sebesar 80,15 . Jadi terdapat kenaikan nilai rata- rata sebesar 2,85 setelah adanya tindakan dengan 2 siklus.

b. Peningkatan juga terjadi pada ketercapaian Kriteria Ketuntasan Minimal (KKM) yaitu pada siklus I jumlah siswa yang mencapai KKM sebesar 60\%, sedangkan pada siklus II jumah siswa yang mencapai KKM sebesar $85 \%$. Jadi terdapat kenaikan sebesar $25 \%$ setelah adanya tindakan dengan 2 siklus.

\section{Saran}

a. Bagi Guru SMK YAPEMDA 1 Sleman

Guru sebaiknya menerapkan variasi strategi pembelajaran agar suasana belajar menjadi menyenangkan sehingga dapat mendorong semangat belajar siswa serta meningkatkan Prestasi Belajar Kompetensi Dasar Mengelola Kartu Utang. Guru sebaiknya menerapkan Strategi Pembelajaran Aktif Tipe Instant Assessment pada mata pelajaran atau kompetensi dasar lain, karena strategi pembelajaran ini telah dapat meningkatkan Prestasi Belajar Kompetensi Dasar Mengelola Kartu Utang. Guru sebaiknya memberikan siswa latihan soal dan tugas. Hal ini karena siswa dapat menjadi lebih aktif dalam mengikuti pembelajaran. Pemberian latihan soal dan tugas juga dapat mendorong siswa agar lebih tekun serta rajin dalam mencari materi dari berbagai sumber.

b. Bagi Peneliti Selanjutnya

Saran untuk peneliti yang akan melakukan penelitian dengan penerapan Strategi Pembelajaran Aktif Tipe Instant Assessment yakni sebaiknya untuk mempersiapkan dengan baik pelaksanaan penelitian khususnya dalam hal alokasi waktu sehingga pembelajaran dapat terlaksana dengan lancar. Peneliti juga perlu membangun komunikasi dan kerjasama yang baik dengan guru mata pelajaran.

\section{DAFTAR PUSTAKA}


Depdikbud. (2006). Undang-undang Sistem Pendidikan Nasional. Yogyakarta: Pusat Pelajar.

Dwi Siswoyo, dkk. (2008). Ilmu Pendidikan. Yogyakarta: UNY Press.

Hendi Soemantri (2011). SMK Akuntansi Seri $D$. Bandung: Armico.

Kunandar. (2012). Langkah Mudah Penelitian Tindakan Kelas Sebagai Pengembangan Guru. Jakarta: Rajawali Pers.

Mulyasa. (2016). Praktik Penelitian Tindakan Kelas. Bandung: PT Remaja Rosdakarya.

Rusman. (2010). Model-Model Pembelajaran Mengembangkan Profesionalisme Guru. Jakarta: Raja Grafindo Persada.

Silberman, Melvin. (2016). Active Learning: 101 Cara Belajar Siswa Aktif. Bandung: Nuansa.

Suharsimi Arikunto, dkk. (2006). Penelitian Tindakan Kelas. Jakarta: PT Bumi Aksara.

Wina Sanjana. (2013). Strategi Pembelajaran Berorientasi Standar Proses Pendidikan. Jakarta: Kencana Prenada Media Group.

Zainal Arifin . (2016). Evaluasi Pembelajaran. Bandung: Remaja Rosdakarya 